R. História, São Paulo. 120, p.45-57. jan/jul. 1989.

\title{
ALFORRIAS, LITÍgIOS E A DESAGREGAÇÃO DA ESCRAVIDÃO INDÍGENA EM SÃO PAULO*
}

\author{
John M. Monteiro**
}

RESUMO: O autor documenta o declínio da concentração de máo-de-obra indígena em São Paulo na conjuntura de 1690 a 1730 através de um cauteloso estudo dos inventários c das cartas de alforria. Assinala as dificuldades de serem implementadas as alforrias condicionais e o lento crescimento de uma população pobre e destituída de Índios libertos. A partir das descobertas do ouro, constata um recrudescimento da presença de ouvidores e autoridades da Justiça metropolitana, apoiando os litígios e petições dos índios forros. A crescente resistência dos índíos acelera o fim da escravião indígena. Os documentos nuançam diferentes estratégias de controle do trabalho servil e seu lento desaparecimento.

UNITERMOS: São Paulo colonial, escravidão indígena, trabalho forçado, alforrias condicionais.

"A história dos índios é o opprobrio da nossa civilização. Apesar de tantas leis proclamando a sua liberdade e prescrevendo a escravidão deles, esta subsiste quase de facto!" ". Quando pronunciou estas palavras no seu Relatório de 1858, o Presidente da Província de Amazonas Francisco José Furtado certamente dirigia uma crítica à política indigenista exercida no Império. Suas observações ressoam, porém, num plano histórico muito mais amplo, na medida em que ressaltam as contradições básicas desa política, presentes desde as primeiras manifestações de uma legislação "protetora" dos interesses dos aborígenes, ainda no século XVI.

\footnotetext{
Uma versão preliminar deste trabalho foi apresentado no Congresso Internacional da Escravidão na USP em maio de 1988.

** Departamento de Economia/UNESP/Araraquara.

1 VARnhagen, Francisco Adolfo de. Os índios Bravos e o Sr. Lisboa. Lisboa, 1867.
} 
MONTEIRO, John M. Alforrias, litígios e a desagregação da escravidão indígena em Sao Piulo.

A história dos índios do Brasil, contudo, não se esgota com a história da política indigenista. Nem é possível entender de forma satisfatória a escravidão indígena através do conteúdo ambíguo e contraditório da legislação oficial. Na verdade, tanto a escravidão indígena quanto as leis governando a política indigenista surgiram de um processo histórico concreto, o qual resultou nas estruturas de dominação, que tornaram a subordinar grande parte das sociedades indígenas do Brasil aos interesses do colonialismo europeu.

O verdadeiro abismo entre o espírito da legislação indigenista e a realidade das relações euro-indígenas manifestou-se de forma clara e contundente em São Paulo colonial. Apesar de um vasto repertório de leis régias e de bulas papais a favor da liberdade dos índios, começando com a famosa lei de 1570 e reafirmada em 1596, 1609, 1611, 1639 e 1696, surgiram, em São Paulo colonial, relações de exploração nitidamente escravistas. Embora os contornos institucionais do cativeiro fossem ocultados pelo regime paralelo de administração particular, na verdade os colonos paulistas guardavam para si direitos quase irreversíveis sobre as pessoas e propriedades dos índios sob a sua dominação direta. De fato, os índios administrados eram vendidos e trocados rotineiramente como propriedade e transmitidos regularmente para novos donos através de heranças. Ademais, a única maneira de se ver livre do cativeiro - fora as formas convencionais de rebeldia e resistência, comuns a todas as sociedades escravistas -, era através da alforria, passada em testamento ou em escritura devidamente registrada no cartório ${ }^{2}$.

$\mathrm{O}$ que se pretende com este artigo é enfocar particulannente um dos aspectos das relações escravistas que vigoraram ao longo do século XVII em São Paulo. Ao examinar as formas pelas quais índios escravizados adquiriam sua liberdade, procurar-se-á demonstrar como as alforrias e ações litigiosas a favor da liberdade de índios contribuíram para a aceleração da desagregação da escravidão indígena na região. Nesse sentido, o trabalho visa apresentar alguns elementos para uma discussão mais abrangente da questão do trabalho indígena na colônia, questão esta que permanece pouco elaborada na historiografia brasileira.

2 A gênese e desenvolvimento da escravidão indígena durante o século XVII é discutido mais detalhadamente em: MONTEIRO, John. From Indian to Slave: Forced Native Labour and Colonial Society in São Paulo During the Seventeenth Ceatury. Slavery ami Abolition. Londres, v.9,n. 2, p. 105-127,1988. 
Ao longo do século XVII, as atividades econômicas dos colonos da região de São Paulo assentaram-se numa ampla e sólida base de escravos índios, aprisionados nas freqüentes expedições dos paulistas ao sertão. Um fluxo constante de novos índios, que atingiu o seu auge no meio do século, abasteceu as fazendas e sítios da região planai tina, bem como proporcionou uma mão-de-obra excedente, que se empregava sobretudo no transporte de produtos locais, que se destinavam ao mercado litorâneo. Essa relação essencial entre mão-de-obra abundante e a agricultura comercial definiu os contornos da sociedade paulista no século XVII e, ao mesmo tempo, ligou São Paulo aos quadros da economia colonial.

A partir da segunda metade do século, o fornecimento da mão-de-obra indígena através das chamadas "bandeiras" tomou-se crescentemente difícil pois, as expedições de apresamento enfrentaram sertões pouco conhecidos, distâncias mais dilatadas e maior resistência indígena. O declínio na rentabilidade das expedições provocou uma crise séria na economia paulista. A maioria dos produtores rurais, dispondo de apenas alguns cativos índios, afastaram-se da produção comercial enquanto outros - aqueles que conseguiram manter uma força de trabalho considerável -, começaram a orientar recursos para outras atividades. Alguns introduziram escravos africanos em suas fazendas, procurando de forma consciente substituir a população cativa, que declinava. Outros lançaram mão da criação de animais de carga, numa tentativa de substituir as reservas de carregadores índios. E haviam outros, ainda, como no conhecido exemplo de Fernão Dias Pais, que enterravam seus recursos e esperanças na busca de metais preciosos ${ }^{3}$.

Apesar de fortes sinais preconizando o declínio da escravidão indígena, ela permanecia fortemente enraizada em São Paulo na época em que foi descoberto o ouro, na década de 1690. Diversos fazendeiros continuavam a comandar posses superiores a cem escravos. No plano institucional, os direitos dos colonos para com o serviço particular dos índios estavam razoavelmente bem definidos, graças ao acordo alcançado em 1696, envolvendo colonos, jesuítas e a coroa ${ }^{4}$.

3 Para uma discussão mais[ elaborada da relação entre a escravião indígena e a economia local no sécuto XVII, ver: MONTEIRO, John. Celeiro do Brasil: Escravidão Indígena e a Agricultura Paulista no Século XVII, História. São Paulo, v. 7, p. $1-12,1988$.

4 MONTEIRO, John, São Paulo in the Seventeenth Century: Economy and Society. Tese de Doutorado, University of Chicago, 1985, Capítulo 3. 
MONTEIRO, John M. Alforriai, litígios e a desagregação da escravidão indígena em São Pauto.

Mesmo assim, a corrida para as minas aprofundou a crise da escravidão indígena em diversos sentidos. Muitos paulistas, sobretudo aqueles com poucos escravos, migraram para as minas, o que redundou num êxodo considerável da mão-de-obra local, êxodo esse que foi assunto tanto nas reuniões das câmaras municipais, quanto na correspondência entre funcionários da coroa. De fato, o que se percebe na documentação local, sobretudo nos inventários, é um declínio vertiginoso na concentração de mão-de-obra indígena na região ${ }^{5}$.

Como agravante, ao fixar suas atenções nas oportunidades econômicas propocionadas pela abertura das minas, os paulistas praticamente suspenderam as suas atividades de apresamente, que eram fundamentais para a reprodução da escravidão indígena. Alguns cativos originários das minas foram transferidos para São Paulo no início do século XVIII, mas eram poucos pois, grande parte das populações dessa região já havia sido deslocada, devido à presença constante de expedições de apresamento, as quais datavam dos anos $1660^{6}$. As demais sociedades remanescentes nas imediações das minas desapareceram rapidamente, dizimadas por doenças infecciosas ou deslocadas para áreas ainda não ocupadas pelos brancos.

Assim, no início do século XVIII, o processo de dominação que havia caracterizado as relações luso-indígenas na região, desde os fins do século XVI, manifestava-se em pelo menos dois sentidos fundamentais, deixando marcas profundas na sociedade paulista. Em primeiro lugar, as relações forjadas entre senhores e fndios definiram os extremos da estrutura de dominação, estabelecendo os fundamentos de uma sociedade escravista bem caracterizada. E em segundo, a distribuição desigual dos cativos, situação essa que se agravara com a crise do apresamento, determinou diferenças marcantes

5 Embora não existam dados precisos referentes à população indígena para este período, os inventários fornecem uma imagem clara de declínio. No auge da escravidão indígena, na década de 1640 , o tamanho médio de posse inventariada ultrapassava 38; esta cifra cai para 23 na década de 1680,14 na de 1690 e menos de 10 depois de 1710. MONTEIRO, John, São Paulo in the Seventeenth Century, Quadra 1.

6 Por exemplo, João Pedroso Xavier, um dos descobridores de ouro em Sumidouro, integrou cerca de vinte Índios oriundos das minas a sua fazenda em Parnaíba durante a primeira década do século XVIII. Arquivo do Estado de São Paulo, inventários não publicados, DAESP-Inventários, caixa 24. ver também "Coleção das Notícias dos Primeiros Descobrimentos das Minas na América", (Códice Costa Matoso), BMSP, fis. 14. 
R. Historia, São Paulo. 120, p. 45-57. jan/jul. 1989.

entre alguns poucos colonos ricos e a grande maioria, a qual se achava cada vez mais submersa num estado de pobreza rural ${ }^{7}$.

Ill

Na medida em que a distância entre os grandes proprietários de terras e escravos se alargava, a proximidade entre homens livres pobres e escravos índios tornava-se mais evidente. Em certo sentido, a distância social entre fndíos e brancos em São Paulo sempre fora pequena pois, mesmo os maiores proprietários, aqueles que inclusive se consideravam a nobreza da terra, enfrentavam dificuldades em esconder traços de ascendência indígena nas suns genealogías ${ }^{8}$. No entanto, com a evolução da escravidão, tal proximidade étnica cedia lugar a distinções baseadas em posição social e nas relações de produção. Estas distinções permaneciam importantes para a maioria dos senhores de escravos índios. Por exemplo, Amador Bueno da Veiga, senhor de mais de cem índios e algumas dezenas de africanos, demonstrou profundo desgosto para com a sua irma-de-criação, uma mameluca filha de índia, quando esta se dispôs a casar com um índio escravo do seu irmão ${ }^{9}$.

Portanto, a escravidão produziu constantemente situações que acusavam a proximidade entre brancos e índios, mediada peta existência de uma larga camada de pessoas de condição incerta. O testamento de Antonio $\mathrm{Nu}$ nes revela um detalhe bastante interessante nesse sentido- "Declam que tenho um moço do gentío da terra da minha obrigação que é meu tio, irmão de minha mãe, casado com uma índia da aldeia e assim por bons serviços que me tem feito ... o deixo forro e livre" ${ }^{10}$.

7 Ver nosso Distribuição de Riqueza e as Origens da Pobreza Rural cm São Paulo no Século XVII", Estudos Econômicos. São Paulo, v. 19, n. 1, p.109-130,1989.

8 A respeito, ver SCHWARTZ, Stuart. The Formation of a Colonial Identity in Brazil. In CANNY, N. e PAGDEN, A. (orgs.) Colonial Identity in the Atlantic World. Princeton: Princeton University Press. 1987, pp. 15-50; e ABUD, Kátía Maria . $O$ Sangue Intimorato e as Nobilísimas Tradições (A Construção de um Símbolo Paulista: O Bandeirante). Tese de Doutorado, Universidade de São Pau$10,1985$.

9 FOnSECA, Pe. Manuel da. Vida de Belchior de Pontes. São Paulo: Melhoramento, S.d., p. 109-110.

10 Testamento de Antonio Nunes, 1643, DAESP, Inventários e Testamentos 1921-77. São Paulo: Arquivo do Estado, v. 38, p. 19. 
MONTEIRO, John M. Alforrias, litigios e a desagregação da escravidão indigena em São Paulo.

A integração de ex-escravos na sociedade livre se tornou mais usual pelo fim do século XVII, o que teve o duplo efeito de acelerar o processo de declínio da escravidão indígena e, de um outro lado, de aumentar a população pobre do campo e das vilas. Os registros paroquiais de Santo Amaro, para citar um exemplo, demonstram uma alta incidência de filhos ilegítimos de mães índias ou bastardas e de pais incógnitos ${ }^{11}$. Nos casos onde a paternidade vem reconhecida, as crianças sempre foram consideradas livres, a despeito do dispositivo legal que rezava, no latim de um ouvidor da época, partus sequibus ventrum. ou seja, o filho segue o foro da mãe. Alguns destes pais provenientes das camadas mais proeminentes, para tirar dúvidas, concediam a liberdade às mães, as vezes doando-lhes terras e escravos. Por exemplo, Pedro Vaz de Barros, fundador da grande fazenda de Carambeí e da capela de São Roque, teve quatorze filhos bastardos com seis escravas diferentes, sendo que alforriou todas e as dotou com generosas concessões de terras e de índios, quando da sua morte.

Assim, sobretudo a partir dos últimos anos do século XVII, índios alforriados contribuíram para a expansão de uma população de condição incerta, entre a escravidão e a liberdade. Praticava-se a alforria ao longo do período escravista mas, com o declínio da agricultura comercial e o empobrecimento conseqüente de muitos colonos, senhores pareciam mais dispostos a conceder cartas de liberdade a seus índios. Nesse sentido, é importante distinguir entre os testamentos que declaravam a liberdade dos índios como princípio geral e aqueles que tomaram um passo a mais, isto é, deixando os índios livres de verdade. No mais das vezes, senhores moribundos, num ultimo suspiro paternalista, reconheciam dúvidas quanto à legitimidade do cativeiro indígena, garantindo porém, no mesmo suspiro, que estes índios "livres" fossem repartidos entre seus herdeiros. Assim, a diferença crucial residia na estipulação adicional, que isentava os índios de qualquer serviço posterior à morte do senhor, estipulação esta muito menos freqüente.

De fato, a liberdade concedida num testamento, as vezes reiterada numa carta de alforria depositada no cartório, era considerada irreversível, $\mathrm{H}$

11 Dos 318 filhos de índias e bastardas, batisados cm Santo Amaro nos anos derradeiros do sáculo XVII, 169 (53\%) foram registrados com "pai incógnito", enquanto 139 (44 \%) foram filhos de casais declarados. ARQUIVO DA CÚRIA METROPOLITANA DE SÃO PAULO, 04-02-23, Batisados, Santo Amaro, Livro 1. Ver também MONTEIRO, John. São Paulo in the Seventeenth Century. Quadra 14 .

12 Testamento de Pedro Vaz de Barros, 1674. no inventário de Brás de Marros, DAESP -Inv. ex. 22. 
R. História, São Paulo, 120, p.45-57, jan/jul. 1989.

despeito de litigios ocasionais movidos por herdeiros inconformados. Ines Pedroso, por exemplo, ao alforriar Generosa e Custódia "por boas obras", enfatisou que as duas "ficarão forras e livres em obrigação de servidumbre alguma nem o filho nem a filha e se poderão ir para a aldeia ou para onde lhe parecer" 13. Para citar outro caso com desfecho diferente, Madalena, uma índia libertada em circunstâncias semelhantes por sua senhora Luzia Leme, teve de recorrer à justiça comum para garantir a dádiva, já que um herdeiro a mantinha no cativeiro. Na sentença, o juiz estabeleceu uma multa de 20 milreis, valor provável da moça, para "quem a estorvasse" ${ }^{14}$. Talvez achando pouca garantia na justiça, outro senhor protegeu uma alforriada de outro modo, proibindo a sua exploração pelos herdeiros "debaixo de minha maldição" ${ }^{15}$.

Em São Paulo, a alforria condicional constava como a forma mais comum da passagem de escravo a livre. Senhores muitas vezes estipularam que os índios teriam de servir herdeiros, sendo que, com a morte destes, consumar-se-ia a alforria. Do ponto de vista senhorial, este tipo de ação tinha a dupla vantagem de aliviar a consciência na hora da morte e, ao mesmo tempo, oferecer alguma garantia de mão-de-obra ou renda para os herdeiros. Para os fndios, seria a liberdade condicional vantajosa apenas no caso do senhor que condicionava a liberdade à morte do cônjuge sobrevivente, igualmente idoso. Para a maioria, contudo, resignada a servir os filhos do seu senhor "benevolente", a liberdade não era tão próxima. Salvo a ocasião rara em que os herdeiros que dispunham de fndios condicionalmente alforriados completaram o desejo dos pais, passando carta de alforria definitiva. Por exemplo, o Capitão Guilherme Pompen de Almeida registrou uma carta de alforria no cartório de Parnaíba, concedendo liberdade ao casal João e Isabel, junto com os filhos, assim realizando a verba do testamento da sua mãe, que havia deixado a família livre sob a condição de servirem os herdeiros ${ }^{16}$.

Outras alforrias condicionais estipulavam tarefas específicas ou outros termos de serviço. Por exemplo, José Ortiz de Camargo esboçou um arran-

13 Conquanto a questão da liberdadedos índios tenha sido amplamente discutido na historiografia, sobretudo nos seus aspectos legislativos, a questão da alforria mal tem sido abordada. Uma exceção notável, referente ao Maranhão, é: SWEET, David. Francisca: Indian Slave. In: SWEET, D. e NASH, G. (orgs.), Struggle and Survival in Colonial America. Berkeley: University of California Press, 1981.

14 DAESP, Testamento de Ines Pedroso, 1632. Inventários e Testamentos, v. 8, p, 365.

15 DAESP, Petição de Madalena India, 18/6/1634, Inventários e Testamentos, v. 9, p. 9.

16 DAESP, Testamento de Francisco Pinto Guedes, 1701, Primeiro Ofício, 13998. 
MONTEIRO, John M. Alforrias, litigios e a desagregação da escravidão indígena em São Paulo.

jo complicado na carta de alforria de seu escravo especializado, Paulo. Segundo a mesma, Paulo gozaría de urna semana livre cada mês para passar com sua mulher, que morava em outra fazenda e, durante as outras semanas, ensinaria a oito índios escravos os segredos do seu ofício. No término de seus anos, ficaria livre incondicionalmente ${ }^{17}$.

Mas estes tipos de condição poderiam, eventualmente, causar certa confusão, como no caso das bastardas Mônica e Felipa. Margarida Gonçalves, a senhora das duas, achou necessária e justa a revogação da alforria que tinha-lhes sido concedida, visto que as moças foram direto para a vila de São Paulo, pensando que já estivessem livres, ao invés de aguardar o falecimento da senhora, conforme condicionava a carta de alforria. Gonçalves justificou esta ação ao observar que as duas "eram ingratas e eram suas escravas, sendo filhas de sua negra" ${ }^{18}$. Sorte semelhante teve José mameluco, filho de homem branco com uma índia Tememinó. Seu senhor, o Padre Antonio Rodrigues Velho de Jundiaí, tinha passado sua carta de alforria em 1672, revogando-a, porém, nove anos depois "por ingratidão" ${ }^{19}$.

Alforrias incondicionais eram bem mais raras. Em um caso, a "negra da terra" Maria conseguiu sua liberdade imediata ao depositar 32 milreis, seu valor de mercado, nas mãos dos herdeiros de Luzia Leme ${ }^{20}$. Em caso semelhante, Sebastiana de Oliveira concedeu liberdade a sua fndia Páscoa ao receber 200 milreis, "que me deu por agradecida de a deixar por forra e livre" 21.

De modo geral, os senhores procuravam manter os libertos nas fazendas, mesmo quando a alforria fosse incondicional. Muitas vezes, certos membros de uma família recebiam a alforria, enquanto seus cônjuges e filhos permaneciam na condição de "serviços obrigatórios". Por exemplo, Gaspar Favacho concedeu alforria a diversos índios no seu testamento, sendo que todos teriam de permanecer na fazenda para se manter unidos às famílias ${ }^{22}$. De fato, ao longo do período escravista, era comum encontrar libertos na composição da força de trabalho nas fazendas, ora para se manterem juntos às famílias, ora simplesmente coagidos.

17 DAESP, Carta de Alforria, 1690, Notas de Parnaíba.

18 Carta do Alforria de José Ortiz de Camargo a Paulo, 1663, Cartório do Primeiro Ofício, Jundiaí, Notas 1663, f. 35.

19 DAESP, Reclamação de uma Alforria, 1/3/1681, Notas Parnaíba 1680.

20 Carta de Alforria, 28/7/1672 e Escritura Destratando Alforria, 11/1/1681, Livros de Notas de lundiái, Cartório do Primeiro Oficio, Jundiaí.

21 DAESP, Carta de Alforria, 8/2/1700, Notas Parnaíba, 1699.

22 DAESP, Testamento de Sebastiana de Oliveira, 1713, Inv. Cx. 25. 
Em todo caso, a opção entre ficar ou deixar a unidade do seu ex-senhor dependia, em última análise, das perspectivas de sobrevivência dentro dos contextos econômicos e sociais de São Paulo colonial. Os dez ex-escravos de Maria de Lima Barbosa optaram permanecer junto ao fílho da defunta, talvez por falta de alternativa ${ }^{23}$. Mas alguns senhores mostraram alguma preocupação com a sorte dos ex-cativos, dando-lhes ferramentas, terras e mesmo dinheiro para ampará-los nas suas novas vidas. Angela de Siqueira, para citar outro exemplo, deu 20 milreis a uma bastarda "que assiste na minha casa ... por bons serviços" ${ }^{24}$. E Ambrósio Mendes, por sua parte, ao libertar todos os cativos índios, concedeu a cada casal duas enxadas, uma foice e um machado, "para que tenham com que remediar suas vidas". Esta concessão, segundo o ex-senhor, seria recompensa aos índios "de me haverem servido" ${ }^{25}$.

\section{IV}

Nem todos os índios podiam contar com a boa vontade de seus senhores para garantir a sua liberdade e sobrevivência. Se os problemas econômicos amaciaram os temperamentos de alguns senhores, endureceram o de outros, que aumentavam as suas exigências em face de uma crise comercial. Como resultado, muitos índios acharam necessário lutar por sua autonomia e liberdade, lançando mão de meios tanto ilegais quanto legais. Assim, ao passo que aumentavam as fugas individuais, também aumentavam os litígios movidos por índios em prol da liberdade ${ }^{26}$.

De fato, no alvorecer do século XVIII, a despeito da regularização da relação senhor-administrado através de uma carta régia de 1696, os índios começavam a conscientizar-se das vantagens do acesso à justiça colonial, sobretudo com respeito à questão da liberdade. Isso foi possível, em larga medida, devido às reformas administrativas que foram implantadas a partir da década de 1690. Estas reformas, embora alcançando êxito apenas parcial, visavam subordinar a região à autoridade da coroa, entendido isto como particularmente necessário depois da descoberta de ouro nas Gerais. A maneira

23 DAESP, Testamento de Gaspar Favacho, 1681, Inv. cx. 16.

24 DAESP, Inventário de Maria do Uma Barbosa, 1715, Inv. Cx. 26.

25 DAESP, Testamento de Angela do Siqueira, 1728, Inv. cx. 32,

26 DAESP, Testamento de Ambrôsio Mendes, 1642,Inventários e Testamentos, v. 13, p. 481 . 
MONTEIRO, John M. Alforrias, litígios e a desagregação da escravidão indígena em São Paulo

mais direta de efetivar tal subordinação seria através da intromissão da coroa nas relações entre colonos e índios. Apesar de não abolir efetivamente a escravidão indígena - a "abolição" já tinha sido feito inúmeras vezes -, a presença da administração real na questão indígena em São Paulo neste período, de fato acelerou o processo de desagregação ${ }^{27}$.

Um dos resultados diretos deste movimento foi a maior disponibilidade da justiça colonial nas disputas em tomo da questão indígena. Pela primeira vez, surgia uma base pela qual a legislação referente à liberdade dos índios foi defendida. Durante o século XVII, tentativas de adequar as relações de trabalho vigentes ao corpo legislativo indigenista fracassaram, justamente pelas contradições ali suscitadas. Os colonos, amparados pela justiça ordinária, sediada aliás nas câmaras municipais, forjaram os contornos institucionais do serviço obrigatório a título de direitos adquiridos, ou seja, provenientes do "uso e costume." Assim, quando surgiu um questionamento em torno do direito de transmissão dos índios a herdeiros, prevaleceu o "uso e costume"28. Em outro caso notável - um litígio sobre a posse de alguns cativos -, apesar de exaustiva citação da legislação indigenista, o direito da propriedade tomou precedência sobre o direito da liberdade ${ }^{29}$.

Estas tendências começaram a mudar com a intromissão da justiça régia na região, sobretudo quando da chegada do primeiro ouvidor permanente em São Paulo, nos anos finais do século XVII. A partir de então, os próprios índios passaram a ser freqüentes autores de petições e litígios, buscando a liberdade, a partir de argumentos fundamentados num conhecimento da legislação em vigor.

Um caso ilustrativo deste processo ocorreu em 1721, na vila de Itu. Micaela Bastarda, que havia sido alforriada em 1703 por Gonçalo de Pedrosa, deixando-a "livre de toda a servidão e administração para poder viver como pessoa livre com quem quiser." No entanto, o Prior do Carmo a força-

A questão das fugas é discutida em John Monteiro, From Indian to Slave, p. 121-124.

28 LEME, Pedro Taquea de Almeida Pais, Nobitiarquia Paulistana, Histórica e Genealdgica. (Sao Paulo: EDUSP, 1980. 3 vols.), HI, p. 19, afirma que a escravidão indígena foi extinta em todo Brasil por volta de 1732. Esta afirmação está equivocada pois, na verdade, o evento a que se refere foi um bando do governador Sarzedas exigindo que todos os indios fossem colocados nos aldeamentos, para que pudessem ser utilizados nas guerras contra os Paiaguá de Mato Grosso. Este erro foi repetido por muitos autores.

29 MONTEIRO, John. São Paulo in the Seventeenth Century;p. 144-149. 
R. História, São Paulo, 120, p.45-57, jan/jul. 1989.

va a trabalhar no Convento de São Luís, posto que a viúva do mesmo senhor legara seus indios ao convento em escritura posterior ao testamento. Em defesa dos interesses do convento, o Prior argumentava ser "uso e costume há mais de 150 anos servir de gentío, mamalucos e bastardos" e, ademais, "passar a administração de uns para outros, de pais para filhos." Por sua parte, o procurador representando Micaela colocou que "uso e costume não pode ter lugar onde há lei em contrário e também contra as liberdades não há nem pode haver prescrição ainda imemorial." Depois de muitas audiências, o juiz ordinário Claudio Furquim de Abreu pronunciou sentença a favor de Micaela, garantindo a sua liberdade e obrigando os padres a pagar serviços referentes aos doze anos e sete meses durante os quais Micaela foi "injusta e violentamente" explorada. Os padres não chegaram a pagar a indenização à "pobre miserável" mas, depois de quase vinte anos de incerteza, Micaela ganhou sua liberdade, abrindo, aliás, precedente para os demais índios do convento ${ }^{30}$.

Mas a classe senhoria] mostrou-se bastante obstinada frente a estas mudanças, segurando os ultimos índios escravos a todo custo. Por exemplo, Francisco Dias e sua mulher Ursula, índios da aldeia de Escada (hoje Guararema), "livres de nascimento", entraram com uma ação, alegando que sua filha estava no poder de um Marcos da Fonseca de Mogi das Cruzes, que tratava a menina como se fosse escrava. Pediram ao juiz que restituísse a menina para a aldeia, para gozar da liberdade a que tinha direito. No entanto, o caso foi investigado pelo capitão da vila, determinando que Fonseca tratava bem a menina e recomendando a suspensão do litígio ${ }^{3 \mathrm{I}}$. Assim, a justiça também podia servir os interesses dos senhores.

De fato, os próprios senhores recorriam mais e mais à justiça para resolverem questões referentes à mão-de-obra indígena. Como desfecho, podemos citar um litígio bastante elaborado, sobre a administração de uma capela rural. Os autos relativos ao processo fornecem dados importantes para a compreensão dos problemas da propriedade de escravos índios e da liberdade dos mesmos, neste período de transição, quando a escravidão indígena sofria um declínio rápido. cX. 1 .

31 DAESP, Micaela Bastarda V. Prior do Carmo, 1721, Autos Cíveis 1700-1800, cx. 15, doc. 320; Sentença Cível a favor de Micaela Bastarda, 1724, Autos Cíveis cx. 13, doc. 190; Domingos Lopes de Godoi v. Convento do Carmo, 1730, Autos Cíveis cx. 25.doc. 428. 
MONTEIRO, John M. Alforrias, litígios e a desagregação da escravidão indígena em São Paulo.

O que se disputava, no fundo, não era a administração da capela mas o controle dos 34 índios a ela vinculados, uma força de mão-de-obra considerável na época, sobretudo naquele bairro pobre de São Miguel ${ }^{32}$. Depois da morte da última filha de Francisco Cubas, fundador da capela de Bonsucesso, a mesma passou para uma sobrinha, casada com João dos Reis Cabral. Cabral moveu uma ação de despejo contra Amador Bueno da Veiga, em cujas mãos se achava a administração da capela. Não satisfeito apenas com o despejo, Cabral também procurou ganhar uma indenização pelo uso do serviço dos índios, calculada em 200 reis por dia por índio, sendo que Amador Bueno usufruiu do trabalho destes índios por dezoito meses.

Evidentemente chocado com a perspectiva de pagar mais de quatro contos de reis pelo trabalho indígena, o qual sempre fora de graça, a primeira reação de Amador Bueno foi de recalcular a conta, determinando que 160 reis por dia seria uma compensação mais justa, visto "umas peças serem de menos serviços que outras e de menos préstimo." Descontou ainda 40 dias por ano "por respeito das águas", além de mais 83 domingos e dias de festa religiosa, durante os quais os índios não trabalhavam. Enfim, chegou a um cálculo que atingia apenas a metade do original, mas que ainda parecia caro. Portanto, o advogado de Amador Bueno recorreu a um argumento complexo, que visava demonstrar que os índios não trabalharam para Amador Bueno, mas apenas para a capela, à qual eles estavam obrigados. Citando a Carta Régia de 1696, o advogado de defesa colocou ainda que "o serviço dos índios pertence aos próprios índios e que os seus administradores lhes paguem." Ao sustentar que Amador Bueno nunca foi administrador desses índios, o advogado mostrou que o réu nada devia. Além do mais, "os trabalhos que fizeram os ditos índios não foram de proveito algum" para Amador Bueno ${ }^{33}$.

Em todo caso, mesmo que o trabalho fosse de algum proveito, Amador Bueno da Veiga, apesar de homem rico, jamais poderia pagar uma conta tão alta, pois isso esvaziaria o sentido da administração particular. Ao que parece, para os paulistas, o trabalho indígena não era compatível com a liberdade

32 Boletim do Arquivo do Estado, v. 5, p. 17-18.

33 A capela, na verdade, localiza-se em Guarulhos, no bairro atual de Bonsucesso. Na época, porém, apesar da distância, fazia parte de São Miguel. 
R.Historia , São Paulo, 120, p.45-57, jan/jul. 1989.

indígena. Nesse novo contexto os colonos teriam de procurar fontes alternativas de mão-de-obra ou, na pior das hipóteses, lavrar a terra com as próprias mãos. •

ABSTRACT: The article analyses the gradual overthrow of indian slavery in colonial São Paulo throughout the period 1690-1730. Through a careful scrutiny of wills and enfranchisement acts, the author documents the decline of the ratio of slave ownership, the difficulties of implementing enfranchisement acts and the gradual appearance of a population of poor and destitute free indians. At the beginning of the gold economy, the presence of crown judicial authorities reinforced the whole process by reasserting the rights of free indians and their resistance to any form of forced labor.

UNITERMS: Colonial São Paulo, indian slavery, forced labor, conditional enfranchisement. 